\title{
Associations of Electronic Device Use Before and After Sleep With Psychological Distress Among Chinese Adults in Hong Kong: Cross-Sectional Study
}

Jung Jae Lee ${ }^{1}$, PhD; Man Ping Wang ${ }^{1}$, PhD; Tzu Tsun Luk ${ }^{1}$, PhD; Ningyuan Guo ${ }^{1}$, BSc; Sophia Siu-Chee Chan ${ }^{1}$, $\mathrm{PhD}$; Tai Hing $\mathrm{Lam}^{2}$, MD

${ }_{1}^{1}$ School of Nursing, University of Hong Kong, Hong Kong, China (Hong Kong)
${ }^{2}$ School of Public Health, University of Hong Kong, Hong Kong, China (Hong Kong)

Corresponding Author:

Man Ping Wang, PhD

School of Nursing

University of Hong Kong

4/F William MW Mong Block Building,

21 Sassoon Rd, Pokfulam,

Hong Kong,

China (Hong Kong)

Phone: 85239176636

Email: mpwang@hku.hk

\section{Abstract}

Background: Hong Kong has a high rate of electronic device (e-device; computer, smartphone, and tablet) use. However, little is known about the associations of the duration of e-device use before and after sleep with psychological symptoms.

Objective: This study aimed to investigate the associations of the duration of e-device use before and after sleep with psychological distress.

Methods: A probability-based telephone survey was conducted on 3162 Hong Kong adults (54.6\% female; mean age 47.4 years, SD 18.3 years) in 2016. Multivariate linear and Poisson regressions were used to calculate adjusted regression coefficients $(\mathrm{aBs})$ and prevalence ratios (aPRs) of anxiety and depressive symptoms (measured by Patient Health Questionnaire-4) for the duration from waking to the first e-device use ( $\geq 61,31-60,6-30$, and $\leq 5$ minutes) and the duration of e-device use before sleeping ( $\leq 5,6-30,31-60$, and $\geq 61$ minutes).

Results: The first e-device use in $\leq 5$ (vs $\geq 61$ ) minutes after waking was associated with anxiety (aB 0.35, 95\% CI 0.24-0.46; aPR 1.74, 95\% CI 1.34-2.25) and depressive symptoms (aB 0.27, 95\% CI 0.18-0.37; aPR 1.84, 95\% CI 1.33-2.54). Using e-devices for $\geq 61$ (vs $\leq 5$ ) minutes before sleeping was also associated with anxiety (aB 0.17, 95\% CI 0.04-0.31; aPR 1.32, 95\% CI 1.01-1.73) and depressive symptoms (aB 0.17, 95\% CI 0.05-0.28; aPR 1.47, 95\% CI 1.07-2.02). E-device use both $\leq 5$ minutes after waking and for $\geq 61$ minutes before sleeping was strongly associated with anxiety (aB $0.68,95 \%$ CI $0.47-0.90 ; \mathrm{aPR} 2.64,95 \% \mathrm{CI} 1.90-3.67)$ and depressive symptoms ( $\mathrm{aB} 0.55,95 \%$ CI 0.36-0.74; aPR 2.56, 95\% CI 1.69-3.88).

Conclusions: E-device use immediately ( $\leq 5$ minutes) after waking and use for a long duration ( $\geq 61$ minutes) before sleeping were associated with anxiety and depressive symptoms among Chinese adults in Hong Kong.

(JMIR Ment Health 2020;7(6):e15403) doi: 10.2196/15403

\section{KEYWORDS}

addictive behavior; anxiety; computers; depression; devices; internet; smartphone; withdrawal symptoms

\section{Introduction}

Electronic devices (e-devices), such as computers, smartphones, and tablets, are forms of information and communication technology (ICT) that have become essential to modern society
$[1,2]$. The penetration rate of e-devices in Hong Kong, one of the most modern cities in China, is among the highest globally (eg, $80.2 \%$ for computers and $88.6 \%$ for smartphones) $[3,4]$.

Given their popularity, the excessive use of e-devices, particularly smartphones, has been increasingly reported [1,5-8]. 
Despite ongoing debates about how to best define excessive use within the domain of addiction, the World Health Organization (WHO) [1] reported that excessive e-device use is arguably a type of behavioral addiction that presents as a repetitive pattern of behavioral engagement in a specific area (ie, e-device use), which eventually affects behavioral engagement in other domains [5,6,9]. Gaming disorders, which are closely associated with e-device use, have recently been included in the WHO's 11th Revision of the International Classification of Diseases (ICD-11) [9].

Increasing concerns have emerged about the adverse psychological effects of behavioral addiction with e-devices $[8,10-17]$. A recent systematic review found that e-device addiction was associated with anxiety ( $\beta$ coefficients, .12-.23) and depression ( $\beta$ coefficients, .15-.48) [15]. These findings were supported by another recent study finding that behavioral addiction to the internet and smartphones resulted in the imbalance of gamma-aminobutyric acid levels in the brain, which has been implicated in the development of depression and anxiety [18].

The WHO has urged the consideration of e-device use duration when defining behavioral addiction with e-devices [1]. Many people start and end their days with e-devices owing to their ubiquity and convenience [19]. Borrowing the concept of adopting the duration of the first tobacco use after waking up in the morning to assess tobacco addiction [20], the duration of the first e-device use may indicate the level of e-device addiction. As negative sleep outcomes, such as shortened sleep duration and sleep onset latency, are associated with excessive bedside e-device use [8,21-23], it is hypothesized that a longer duration of e-device use before sleep (ie, longer screen time before sleep) may also be associated with excessive use and behavioral addiction.

Little is known about the associations of the duration of e-device use before and after sleep with psychological symptoms. Most existing studies have focused on identifying the associations between psychological symptoms and the addiction of e-devices or on developing assessment instruments for e-device addiction [8,10-17]. In addition, most studies have focused only on young age groups, despite the rapid adoption of e-devices among older age groups [24]. Therefore, we aimed to investigate the association of psychological distress with the duration of e-device use before and after sleep in Hong Kong adults.

\section{Methods}

\section{Study Design}

The Hong Kong Family and Health Information Trends Survey (FHInTS) is part of the FAMILY project (A Jockey Club Initiative for a Harmonious Society project). The project has conducted periodic surveys to study family and individual health in relation to the use of ICTs in Hong Kong since 2009. The current FHInTS was the fifth edition of the project, and it explored the areas of ICT use for family health, health communication, and information acquisition [25]. Probability-based telephone surveys of individuals from the general public aged 18 years or older, who had at least one e-device and spoke Cantonese (ie, sample selection criteria), were conducted from January to August 2016 by trained interviewers of the Public Opinion Programme at the University of Hong Kong, a local reputable survey agency.

A random sampling method with two phases was adopted for the survey. Hong Kong's residential telephone directories were used to extract telephone numbers. The last digit of the extracted numbers was converted by adding or subtracting 1 or 2 to make up unlisted numbers in the directories. The telephone numbers were randomly listed using computer software (ie, first phase random sampling). In the second phase, the nearest birthday rule was used to randomly select a respondent [26]. To minimize selection bias by including individuals who work away from home during the day, the telephone survey was mostly conducted in the evenings. Verbal informed consent was collected from each participant over the telephone, and each telephone survey lasted for about 20 minutes. Ethical approval was obtained from the Institutional Review Board of The University of Hong Kong/Hospital Authority Hong Kong West Cluster.

\section{Measurements}

Respondents were asked two questions to obtain the following data that were considered as duration indicators of e-device use: (1) duration from waking to the first e-device use (how long after getting up in the morning do you usually start using your computer, tablet, or smartphone? [response options were $\geq 61$, 31-60, 6-30, and $\leq 5$ minutes]) and (2) duration of e-device use before sleeping (how much time do you spend on using your computer, tablet, or smartphone before sleeping? [response options were $\leq 5, \quad 6-30, \quad 31-60$, and $\geq 61$ minutes]). Duration-related questions have been asked in other e-device addiction studies [13].

Anxiety and depressive symptoms were measured using Patient Health Questionnaire-4 (PHQ-4) [27], a brief self-reported instrument combining Generalized Anxiety Disorder-2 (GAD-2) [28] and Patient Health Questionnaire-2 (PHQ-2) [29] for screening anxiety and depression. GAD-2 and PHQ-2 scores of 3 or above on a scale of 0 to 6 were considered to indicate high risks of anxiety and depression [27]. The Cronbach $\alpha$ of PHQ-4 was .82, and the values of the PHQ-2 and GAD-2 subscales in this study were .71 and .75 , respectively, which were considered satisfactory given their brevity. The score of PHQ-4 correlated well with the score of Perceived Stress Scale-4 [30] in a random subsample of 792 participants $(r=0.61$, $P<.001)$, supporting its convergent validity.

\section{Statistical Analysis}

All data were weighted by age, sex, and education level distributions according to the Hong Kong census data from 2015 [31]. The mean scores of anxiety and depressive symptoms related to sociodemographic characteristics, including sex, age, education level, and household income, and the duration from waking to the first e-device use as well as the duration of e-device use before sleeping were compared using the independent sample $t$ test or one-way analysis of variance (ANOVA), as appropriate. The Spearman rank correlation coefficient was calculated to analyze the correlation between 
the duration from waking to the first e-device use and the duration of e-device use before sleeping. A linear regression was used to compute adjusted regression coefficients (aBs) of anxiety and depressive symptoms for the duration from waking to the first e-device use and the duration of e-device use before sleeping. Age, sex, highest education level, and monthly household income were included in the adjusted regression models. Similar to the linear regression, Poisson regression with a robust variance estimator [32] was used to calculate the adjusted prevalence ratios (aPRs) of risk for anxiety and depression in terms of different durations of e-device use after waking and before sleeping, adjusting for age, sex, education level, and household income. As subgroup analyses, we included multiplicative interaction terms of the participants' durations of e-device use with each demographic in the regression models to compute $P$ values for interaction effects. A sensitivity test was performed by repeating multivariate linear regression models using the PHQ-4 score as the outcome variable.
Available case analysis was used to handle missing data, as the proportion of missing data was very low. Stata version 15 (StataCorp) was used for all analyses, and a $P$ value $<.05$ was regarded as statistically significant.

\section{Results}

\section{Participant Characteristics}

Among 6890 adults eligible for the FHInTS, who were contacted, 5080 successfully completed the interviews (response rate $73.73 \%$ ). Of these 5080 respondents, $3162(62.24 \%)$ possessed at least one e-device and were included in the present study. The mean age of the respondents was 47.40 years (SD 18.32). Additionally, 54.55\% (weighted 1833/3361) were female, $79.77 \%$ (2681/3361) were aged 25 to 64 years, $85.66 \%$ (2879/3361) had secondary or higher education, and $68.42 \%$ (2058/3008) had a monthly household income of HK \$20,000 (US \$2564; US \$1=HK \$7.80) or more (Table 1). 
Table 1. Weighted mean scores of anxiety and depressive symptoms by sociodemographic characteristics in Hong Kong adults who used e-devices.

\begin{tabular}{|c|c|c|c|c|c|c|}
\hline \multirow[t]{2}{*}{ Characteristic } & \multirow[t]{2}{*}{$\begin{array}{l}\text { Value }(\mathrm{N}=3162), \mathrm{n} \\
\left(\%^{\mathrm{a}}\right)\end{array}$} & \multirow[t]{2}{*}{$\begin{array}{l}\text { Weighted value } \\
(\mathrm{N}=3361), \mathrm{n}\left(\%^{\mathrm{a}}\right)\end{array}$} & \multicolumn{2}{|c|}{$\begin{array}{l}\text { Anxiety symptoms (GAD-2 } \\
\text { score; (mean } 1.10, \text { SD } 0.02 \text { ) }\end{array}$} & \multicolumn{2}{|c|}{$\begin{array}{l}\text { Depressive symptoms (PHQ-2 } \\
\text { score; mean } 0.72, \text { SD } 0.02 \text { ) }\end{array}$} \\
\hline & & & Score & $P$ value $^{\mathrm{d}}$ & Score & $P$ value ${ }^{\mathrm{d}}$ \\
\hline Sex & & & & .01 & & .76 \\
\hline Male & $1226(38.77)$ & $1528(45.45)$ & 1.04 & & 0.75 & \\
\hline Female & $1936(61.23)$ & $1833(54.55)$ & 1.13 & & 0.71 & \\
\hline Age (years) & & & & $<.001$ & & $<.001$ \\
\hline $18-24$ & $527(16.67)$ & $382(11.36)$ & 1.67 & & 1.25 & \\
\hline $25-34$ & $325(10.28)$ & $695(20.68)$ & 1.50 & & 1.04 & \\
\hline $35-44$ & $393(12.43)$ & $701(20.87)$ & 1.23 & & 0.80 & \\
\hline $45-54$ & $599(18.94)$ & $725(21.56)$ & 1.03 & & 0.61 & \\
\hline $55-64$ & $715(22.61)$ & $560(16.66)$ & 0.81 & & 0.49 & \\
\hline$\geq 65$ & $603(19.07)$ & $298(8.88)$ & 0.69 & & 0.42 & \\
\hline Education & & & & $<.001$ & & .11 \\
\hline Primary or less & $387(12.24)$ & $482(14.34)$ & 0.79 & & 0.54 & \\
\hline Secondary & $1452(45.92)$ & $1766(52.55)$ & 1.00 & & 0.70 & \\
\hline Tertiary or greater & $1323(41.84)$ & $1113(33.11)$ & 1.29 & & 0.79 & \\
\hline Monthly household income ${ }^{\mathrm{e}}(\mathrm{HK} \$)$ & & & & .13 & & .01 \\
\hline$\leq 19,999$ & $961(34.07)$ & $950(31.58)$ & 1.11 & & 0.77 & \\
\hline $20,000-39,999$ & $928(32.90)$ & $1065(35.40)$ & 1.08 & & 0.74 & \\
\hline$\geq 40,000$ & $932(33.04)$ & $993(33.02)$ & 1.09 & & 0.64 & \\
\hline \multicolumn{3}{|c|}{ Duration from waking to the first e-device use (four categories) } & & $<.001$ & & $<.001$ \\
\hline$\geq 61 \min$ & $1418(45.02)$ & $1409(42.21)$ & 0.92 & & 0.58 & \\
\hline $31-60 \mathrm{~min}$ & $389(12.35)$ & $452(13.53)$ & 1.06 & & 0.77 & \\
\hline $6-30 \mathrm{~min}$ & $628(19.94)$ & $684(20.49)$ & 1.09 & & 0.74 & \\
\hline$\leq 5 \mathrm{~min}$ & $715(22.70)$ & $793(23.77)$ & 1.47 & & 0.98 & \\
\hline \multicolumn{3}{|c|}{ Duration from waking to the first e-device use (two categories) } & & $<.001$ & & $<.001$ \\
\hline$\geq 6$ min & $2435(77.30)$ & $2544(76.23)$ & 0.99 & & 0.65 & \\
\hline$\leq 5 \mathrm{~min}$ & $715(22.70)$ & $793(23.77)$ & 1.47 & & 0.98 & \\
\hline \multicolumn{3}{|c|}{ Duration of e-device use before sleeping (four categories) } & & $<.001$ & & $<.001$ \\
\hline$\leq 5 \mathrm{~min}$ & $1117(35.51)$ & $1009(30.26)$ & 0.82 & & 0.50 & \\
\hline $6-30 \mathrm{~min}$ & $1033(32.84)$ & $1162(34.85)$ & 1.16 & & 0.74 & \\
\hline $31-60 \mathrm{~min}$ & $559(17.77)$ & $661(19.81)$ & 1.27 & & 0.93 & \\
\hline$\geq 61 \mathrm{~min}$ & $437(13.89)$ & $503(15.08)$ & 1.43 & & 0.98 & \\
\hline \multicolumn{3}{|c|}{ Duration of e-device use before sleeping (two categories) } & & $<.001$ & & $<.001$ \\
\hline$\leq 60 \min$ & $2709(86.11)$ & $2832(84.92)$ & 1.04 & & 0.68 & \\
\hline$\geq 61 \mathrm{~min}$ & $437(13.89)$ & $503(15.08)$ & 1.43 & & 0.98 & \\
\hline Combined duration ${ }^{f}$ & & & & $<.001$ & & $<.001$ \\
\hline$\geq 6 \mathrm{~W}^{\mathrm{g}} \& \leq 60 \mathrm{~S}^{\mathrm{h}}$ & $2144(68.37)$ & $2206(66.46)$ & 0.95 & & 0.62 & \\
\hline$\geq 6 \mathrm{~W}^{\mathrm{g}} \& \geq 61 \mathrm{~S}^{\mathrm{h}}$ & $281(8.96)$ & $325(9.78)$ & 1.24 & & 0.86 & \\
\hline$\leq 5 \mathrm{~W}^{\mathrm{g}} \& \leq 60 \mathrm{~S}^{\mathrm{h}}$ & $555(17.70)$ & $610(18.39)$ & 1.40 & & 0.92 & \\
\hline$\leq 5 \mathrm{~W}^{\mathrm{g}} \& \geq 61 \mathrm{~S}^{\mathrm{h}}$ & $156(4.97)$ & $178(5.37)$ & 1.76 & & 1.19 & \\
\hline
\end{tabular}


${ }^{a}$ Calculated percentages were rounded off to two decimal places, accordingly combined percentages can exceed $100 \%$.

${ }^{\mathrm{b}}$ GAD-2: Generalized Anxiety Disorder Questionnaire-2.

${ }^{\mathrm{c}}$ PHQ-2: Patient Health Questionnaire-2.

${ }^{\mathrm{d}} P$ for $t$ test (two groups) or ANOVA (three groups or above).

${ }^{\mathrm{e}} \mathrm{US} \$ 1=\mathrm{HK} \$ 7.8$.

${ }_{\mathrm{f}}^{\mathrm{f}}$ Duration from waking to the first e-device use plus duration of e-device use before sleeping (two categorizations).

$\mathrm{g}_{6} \mathrm{~W}$ and $5 \mathrm{~W}$ denote the duration from waking to the first e-device use for 6 minutes and 5 minutes, respectively.

${ }^{\mathrm{h}} 60 \mathrm{~S}$ and $61 \mathrm{~S}$ denote the duration of e-device use before sleeping for 60 minutes and 61 minutes, respectively.

\section{Associations of Participant Characteristics With Psychological Distress}

Anxiety symptoms were associated with being female $(P=.01)$, being younger $(P<.001)$, and having higher education levels $(P<.001)$, whereas depressive symptoms were associated with being younger $(P<.001)$ and having lower income $(P=.01)$ (Table 1). Respondents who first used e-devices for shorter durations of time after waking had more anxiety and depressive symptoms $(P<.001)$. Similarly, respondents who used e-devices for longer periods of time before sleeping had more anxiety and depressive symptoms $(P<.001)$. Respondents who first used e-devices within shorter periods of time after waking and for longer periods of time before sleeping had more anxiety and depressive symptoms as compared with other e-device use patterns $(P<.001)$.

\section{Associations of E-Device Use Before and After Sleep With Psychological Distress}

The duration of e-device use before sleeping was significantly correlated with the duration from waking to the first e-device use $\left(r_{\mathrm{s}}=0.304, P<.001\right)$. Shorter periods of time between waking and e-device use (ie, $\leq 5$ minutes) were associated with both anxiety (aB $0.35,95 \%$ CI 0.24-0.46) and depressive symptoms (aB 0.27, 95\% CI 0.18-0.37) (Tables 2 and 3). Shorter durations of time before e-device use were consistently associated with both anxiety (aPR 1.74, 95\% CI 1.34-2.25) and depressive symptoms (aPR 1.84, 95\% CI 1.33-2.54) (Tables 4 and 5). Longer durations of e-device use before sleeping (ie, $\geq 61$ minutes) were associated with higher risks of both anxiety $(\mathrm{aB}$ 0.17, 95\% CI 0.04-0.31; aPR 1.32, 95\% CI 1.01-1.73) and depressive symptoms (aB $0.17,95 \%$ CI $0.05-0.28$; aPR 1.47, $95 \%$ CI 1.07-2.02). The use of e-devices starting $\leq 5$ minutes after waking and for $\geq 61$ minutes before sleeping showed the strongest association with anxiety and depressive symptoms (aB 0.68 and aPR 2.64 for anxiety symptoms; aB 0.55 and aPR 2.56 for depressive symptoms). The results from the sensitivity test, which examined the association of e-device use before and after sleep with PHQ-4 scores, yielded similar results, thus supporting the robustness of the findings. 
Table 2. Linear regression of anxiety symptoms for the duration from waking to the first e-device use and duration of e-device use before sleeping.

\begin{tabular}{|c|c|c|c|c|}
\hline \multirow[t]{2}{*}{ Duration assessed and time $(\min )^{\mathrm{a}}$} & \multicolumn{4}{|c|}{ Anxiety symptoms (GAD- $2^{\mathrm{b}}$ score $)$} \\
\hline & $\begin{array}{l}\text { Crude regression coefficient } \\
(95 \% \mathrm{CI})\end{array}$ & $P$ & $\begin{array}{l}\text { Adjusted }^{c} \text { regression coefficient } \\
(95 \% \mathrm{CI})\end{array}$ & $P$ \\
\hline \multicolumn{5}{|c|}{ Duration from waking to the first e-device use } \\
\hline$\geq 61$ & 0 & & 0 & \\
\hline $31-60$ & $0.03(-0.11$ to 0.17$)$ & .69 & $-0.10(-0.25$ to 0.04$)$ & .17 \\
\hline $6-30$ & $0.07(-0.05$ to 0.20$)$ & .24 & $-0.09(-0.22$ to 0.04$)$ & .18 \\
\hline$\leq 5$ & $0.45(0.34$ to 0.57$)$ & $<.001$ & $0.31(0.18$ to 0.43$)$ & $<.001$ \\
\hline Trend & & $<.001$ & & $<.001$ \\
\hline$\geq 6$ & 0 & & 0 & \\
\hline$\leq 5$ & $0.43(0.32$ to 0.54$)$ & $<.001$ & $0.35(0.24$ to 0.46$)$ & $<.001$ \\
\hline \multicolumn{5}{|c|}{ Duration of e-device use before sleeping } \\
\hline$\leq 5$ & 0 & & 0 & \\
\hline $6-30$ & $0.26(0.15$ to 0.38$)$ & $<.001$ & $0.04(-0.09$ to 0.16$)$ & .54 \\
\hline $31-60$ & $0.41(0.27$ to 0.54$)$ & $<.001$ & $0.16(0.01$ to 0.31$)$ & .03 \\
\hline$\geq 61$ & $0.54(0.40$ to 0.68$)$ & $<.001$ & $0.23(0.07$ to 0.39$)$ & .004 \\
\hline Trend & & $<.001$ & & .002 \\
\hline$\leq 60$ & 0 & & 0 & \\
\hline$\geq 61$ & $0.34(0.21$ to 0.47$)$ & $<.001$ & $0.17(0.04$ to 0.31$)$ & .01 \\
\hline
\end{tabular}

Duration from waking to the first e-device use plus duration of e-device use before sleeping (two categorizations)

$\begin{array}{lllll}\geq 6 \mathrm{~W}^{\mathrm{d}} \& \leq 60 \mathrm{~S}^{\mathrm{e}} & 0 & & 0 & \\ \geq 6 \mathrm{~W}^{\mathrm{d}} \& \geq 61 \mathrm{~S}^{\mathrm{e}} & 0.19(0.04 \text { to } 0.35) & .02 & -0.01(-0.18 \text { to } 0.15) & .87 \\ \leq 5 \mathrm{~W}^{\mathrm{d}} \& \leq 60 \mathrm{~S}^{\mathrm{e}} & 0.35(0.23 \text { to } 0.47) & <.001 & 0.26(0.13 \text { to } 0.38) & <.001 \\ \leq 5 \mathrm{~W}^{\mathrm{d}} \& \geq 61 \mathrm{~S}^{\mathrm{e}} & 0.82(0.61 \text { to } 1.03) & <.001 & 0.68(0.47 \text { to } 0.90) & <.001 \\ \text { Trend } & & <.001 & & <.001\end{array}$

${ }^{a}$ All data were weighted by sex, age, and education level distribution of the Hong Kong general population.

${ }^{\mathrm{b}} \mathrm{GAD}-2$ : Generalized Anxiety Disorder Questionnaire-2.

${ }^{\mathrm{c}}$ Adjusted for age, sex, highest education level, and monthly household income.

${ }^{\mathrm{d}} 6 \mathrm{~W}$ and $5 \mathrm{~W}$ denote the duration from waking to the first e-device use for 6 minutes and 5 minutes, respectively.

${ }^{\mathrm{e}} 60 \mathrm{~S}$ and $61 \mathrm{~S}$ denote the duration of e-device use before sleeping for 60 minutes and 61 minutes, respectively. 
Table 3. Linear regression of depressive symptoms for the duration from waking to the first e-device use and duration of e-device use before sleeping.

\begin{tabular}{|c|c|c|c|c|}
\hline \multirow[t]{2}{*}{ Duration assessed and time $(\mathrm{min})^{\mathrm{a}}$} & \multicolumn{4}{|c|}{ Depressive symptoms (PHQ-2 ${ }^{\mathrm{b}}$ score) } \\
\hline & $\begin{array}{l}\text { Crude regression coefficient } \\
(95 \% \mathrm{CI})\end{array}$ & $P$ & $\begin{array}{l}\text { Adjusted }{ }^{c} \text { regression coefficient } \\
(95 \% \mathrm{CI})\end{array}$ & $P$ \\
\hline \multicolumn{5}{|c|}{ Duration from waking to the first e-device use } \\
\hline$\geq 61$ & 0 & & 0 & \\
\hline $31-60$ & $0.11(-0.02$ to 0.24$)$ & .09 & $0.04(-0.09$ to 0.17$)$ & .52 \\
\hline $6-30$ & $0.09(-0.02$ to 0.20$)$ & .09 & $-0.01(-0.12$ to 0.11$)$ & .92 \\
\hline$\leq 5$ & $0.40(0.30$ to 0.50$)$ & $<.001$ & $0.28(0.17$ to 0.39$)$ & $<.001$ \\
\hline Trend & & $<.001$ & & $<.001$ \\
\hline$\geq 6$ & 0 & & 0 & \\
\hline$\leq 5$ & $0.36(0.26$ to 0.45$)$ & $<.001$ & 0.27 (0.18 to 0.37$)$ & $<.001$ \\
\hline \multicolumn{5}{|c|}{ Duration of e-device use before sleeping } \\
\hline$\leq 5$ & 0 & & 0 & \\
\hline $6-30$ & $0.16(0.06$ to 0.26$)$ & .001 & $0.01(-0.10$ to 0.13$)$ & .79 \\
\hline $31-60$ & $0.41(0.29$ to 0.52$)$ & $<.001$ & 0.19 (0.06 to 0.32$)$ & .005 \\
\hline$\geq 61$ & $0.44(0.31$ to 0.57$)$ & $<.001$ & $0.22(0.08$ to 0.37$)$ & .002 \\
\hline Trend & & $<.001$ & & $<.001$ \\
\hline$\leq 60$ & 0 & & 0 & \\
\hline$\geq 61$ & $0.28(0.16$ to 0.39$)$ & $<.001$ & $0.17(0.05$ to 0.28$)$ & .006 \\
\hline \multicolumn{5}{|c|}{ Duration from waking to the first e-device use plus duration of e-device use before sleeping (two categorizations) } \\
\hline$\geq 6 \mathrm{~W}^{\mathrm{d}} \& \leq 60 \mathrm{~S}^{\mathrm{e}}$ & 0 & & 0 & \\
\hline$\geq 6 \mathrm{~W}^{\mathrm{d}} \& \geq 61 \mathrm{~S}^{\mathrm{e}}$ & $0.16(0.02$ to 0.30$)$ & .02 & $0.03(-0.11$ to 0.18$)$ & .67 \\
\hline$\leq 5 \mathrm{~W}^{\mathrm{d}} \& \leq 60 \mathrm{~S}^{\mathrm{e}}$ & $0.30(0.19$ to 0.41$)$ & $<.001$ & $0.20(0.09$ to 0.31$)$ & $<.001$ \\
\hline$\leq 5 \mathrm{~W}^{\mathrm{d}} \& \geq 61 \mathrm{~S}^{\mathrm{e}}$ & $0.67(0.49$ to 0.85$)$ & $<.001$ & $0.55(0.36$ to 0.74$)$ & $<.001$ \\
\hline Trend & & $<.001$ & & $<.001$ \\
\hline
\end{tabular}

${ }^{a}$ All data were weighted by sex, age, and education level distribution of the Hong Kong general population.

${ }^{\mathrm{b}} \mathrm{PHQ}-2$ : Patient Health Questionnaire-2.

${ }^{\mathrm{c}}$ Adjusted for age, sex, highest education level, and monthly household income.

${ }^{\mathrm{d}} 6 \mathrm{~W}$ and $5 \mathrm{~W}$ denote the duration from waking to the first e-device use for 6 minutes and 5 minutes, respectively.

${ }^{\mathrm{e}} 60 \mathrm{~S}$ and $61 \mathrm{~S}$ denote the duration of e-device use before sleeping for 60 minutes and 61 minutes, respectively. 
Table 4. Poisson regression of anxiety symptoms for the duration from waking to the first e-device use and duration of e-device use before sleeping.

\begin{tabular}{|c|c|c|c|c|c|}
\hline \multirow[t]{2}{*}{ Duration assessed and time $(\min )^{\mathrm{a}}$} & \multirow[t]{2}{*}{ Value, $\mathrm{n}(\%)$} & \multicolumn{4}{|c|}{ Anxiety symptoms $\left(\mathrm{GAD}-2^{\mathrm{b}} \text { score } \geq 3\right)^{\mathrm{c}}$} \\
\hline & & $\begin{array}{l}\text { Crude prevalence ratio } \\
(95 \% \mathrm{CI})\end{array}$ & $P$ & $\begin{array}{l}\text { Adjusted }{ }^{\mathrm{d}} \text { prevalence } \\
\text { ratio }(95 \% \mathrm{CI})\end{array}$ & $P$ \\
\hline \multicolumn{6}{|c|}{ Duration from waking to the first e-device use } \\
\hline$\geq 61$ & $139(9.88)$ & 1 & & 1 & \\
\hline $31-60$ & $44(9.84)$ & $1.00(0.66-1.50)$ & .98 & $0.81(0.52-1.27)$ & .36 \\
\hline $6-30$ & $60(8.75)$ & $0.89(0.62-1.26)$ & .50 & $0.71(0.48-1.04)$ & .08 \\
\hline$\leq 5$ & $135(16.99)$ & $1.72(1.30-2.27)$ & $<.001$ & $1.51(1.12-2.04)$ & .007 \\
\hline Trend & & & .002 & & .04 \\
\hline$\geq 6$ & $218(9.59)$ & 1 & & 1 & \\
\hline$\leq 5$ & $135(16.99)$ & $1.78(1.39-2.27)$ & $<.001$ & $1.74(1.34-2.25)$ & $<.001$ \\
\hline \multicolumn{6}{|c|}{ Duration of e-device use before sleeping } \\
\hline$\leq 5$ & $90(8.89)$ & 1 & & 1 & \\
\hline $6-30$ & $130(11.23)$ & $1.26(0.92-1.73)$ & .14 & $1.00(0.70-1.42)$ & .99 \\
\hline $31-60$ & $76(11.49)$ & $1.29(0.91-1.83)$ & .15 & $0.98(0.66-1.47)$ & .92 \\
\hline$\geq 61$ & $82(16.22)$ & $1.82(1.28-2.60)$ & .001 & $1.31(0.88-1.97)$ & .18 \\
\hline Trend & & & .002 & & .25 \\
\hline$\leq 60$ & $296(10.46)$ & 1 & & 1 & \\
\hline$\geq 61$ & $82(16.22)$ & $1.55(1.16-2.08)$ & .003 & $1.32(0.96-1.82)$ & .09 \\
\hline \multicolumn{6}{|c|}{ Duration from waking to the first e-device use plus duration of e-device use before sleeping (two categorizations) } \\
\hline$\geq 6 \mathrm{~W}^{\mathrm{e}} \& \leq 60 \mathrm{~S}^{\mathrm{f}}$ & $208(9.45)$ & 1 & & 1 & \\
\hline$\geq 6 \mathrm{~W}^{\mathrm{e}} \& \geq 61 \mathrm{~S}^{\mathrm{f}}$ & $31(9.69)$ & $1.03(0.65-1.62)$ & .91 & $0.74(0.48-1.16)$ & .26 \\
\hline$\leq 5 \mathrm{~W}^{\mathrm{e}} \& \leq 60 \mathrm{~S}^{\mathrm{f}}$ & $85(13.87)$ & $1.47(1.10-1.95)$ & .009 & $1.36(1.03-1.79)$ & .047 \\
\hline$\leq 5 \mathrm{~W}^{\mathrm{e}} \& \geq 61 \mathrm{~S}^{\mathrm{f}}$ & $50(28.11)$ & $2.98(2.10-4.22)$ & $<.001$ & $2.64(1.90-3.67)$ & $<.001$ \\
\hline Trend & & & $<.001$ & & $<.001$ \\
\hline
\end{tabular}

${ }^{a}$ All data were weighted by sex, age, and education level distribution of the Hong Kong general population.

${ }^{\mathrm{b}}$ GAD-2: Generalized Anxiety Disorder Questionnaire-2.

${ }^{\mathrm{c}}$ High prevalence of anxiety.

${ }^{\mathrm{d}}$ Adjusted for age, sex, highest education level, and monthly household income.

${ }^{\mathrm{e}} 6 \mathrm{~W}$ and $5 \mathrm{~W}$ denote the duration from waking to the first e-device use for 6 minutes and 5 minutes, respectively.

${ }^{f} 60 \mathrm{~S}$ and $61 \mathrm{~S}$ denote the duration of e-device use before sleeping for 60 minutes and 61 minutes, respectively. 
Table 5. Poisson regression of depressive symptoms for the duration from waking to the first e-device use and duration of e-device use before sleeping.

\begin{tabular}{|c|c|c|c|c|c|}
\hline \multirow[t]{2}{*}{ Duration assessed and time $(\min )^{\mathrm{a}}$} & \multirow[t]{2}{*}{ Value, $\mathrm{n}(\%)$} & \multicolumn{4}{|c|}{ Depressive symptom $\left(\mathrm{PHQ}-2^{\mathrm{b}} \text { score } \geq 3\right)^{\mathrm{c}}$} \\
\hline & & $\begin{array}{l}\text { Crude prevalence ratio } \\
(95 \% \text { CI })\end{array}$ & $P$ & $\begin{array}{l}\text { Adjusted }{ }^{\mathrm{d}} \text { prevalence } \\
\text { ratio }(95 \% \mathrm{CI})\end{array}$ & $P$ \\
\hline \multicolumn{6}{|c|}{ Duration from waking to the first e-device use } \\
\hline$\geq 61$ & $85(6.04)$ & 1 & & 1 & \\
\hline $31-60$ & $24(5.36)$ & $0.89(0.53-1.49)$ & .65 & $0.80(0.45-1.44)$ & .46 \\
\hline $6-30$ & $46(6.72)$ & $1.11(0.71-1.74)$ & .64 & $1.10(0.68-1.79)$ & .69 \\
\hline$\leq 5$ & $98(12.33)$ & $2.04(1.43-2.92)$ & $<.001$ & $1.83(1.23-2.72)$ & .003 \\
\hline Trend & & & $<.001$ & & .005 \\
\hline$\geq 6$ & $137(6.04)$ & 1 & & 1 & \\
\hline$\leq 5$ & $98(12.33)$ & $2.02(1.49-2.75)$ & $<.001$ & $1.84(1.33-2.54)$ & $<.001$ \\
\hline \multicolumn{6}{|c|}{ Duration of e-device use before sleeping } \\
\hline$\leq 5$ & $56(5.53)$ & 1 & & 1 & \\
\hline $6-30$ & $69(5.93)$ & $1.07(0.70-1.65)$ & .75 & $0.77(0.47-1.26)$ & .29 \\
\hline $31-60$ & 71 (10.69) & $1.93(1.25-2.99)$ & .003 & $1.21(0.73-2.03)$ & .46 \\
\hline$\geq 61$ & $54(10.78)$ & $1.95(1.23-3.10)$ & .005 & $1.40(0.83-2.36)$ & .21 \\
\hline Trend & & & $<.001$ & & .049 \\
\hline$\leq 60$ & $195(6.90)$ & 1 & & 1 & \\
\hline$\geq 61$ & $54(10.78)$ & $1.56(1.08-2.26)$ & .02 & $1.47(1.07-2.02)$ & .02 \\
\hline \multicolumn{6}{|c|}{ Duration from waking to the first e-device use plus duration of e-device use before sleeping (two categorizations) } \\
\hline$\geq 6 \mathrm{~W}^{\mathrm{e}} \& \leq 60 \mathrm{~S}^{\mathrm{f}}$ & $127(5.78)$ & 1 & & 1 & \\
\hline$\geq 6 \mathrm{~W}^{\mathrm{e}} \& \geq 61 \mathrm{~S}^{\mathrm{f}}$ & $24(7.49)$ & $1.30(0.77-2.17)$ & .32 & $1.18(0.74-1.87)$ & .48 \\
\hline$\leq 5 \mathrm{~W}^{\mathrm{e}} \& \leq 60 \mathrm{~S}^{\mathrm{f}}$ & $68(11.13)$ & $1.93(1.35-2.75)$ & $<.001$ & $1.66(1.19-2.31)$ & .003 \\
\hline$\leq 5 \mathrm{~W}^{\mathrm{e}} \& \geq 61 \mathrm{~S}^{\mathrm{f}}$ & $30(16.78)$ & $2.91(1.79-4.73)$ & $<.001$ & $2.56(1.69-3.88)$ & $<.001$ \\
\hline Trend & & & $<.001$ & & $<.001$ \\
\hline
\end{tabular}

${ }^{\mathrm{a}}$ All data were weighted by sex, age, and education level distribution of the Hong Kong general population.

${ }^{\mathrm{b}} \mathrm{PHQ}-2$ : Patient Health Questionnaire-2.

${ }^{\mathrm{c}}$ High prevalence of depression.

${ }^{\mathrm{d}}$ Adjusted for sex, age, highest education level, and monthly household income.

${ }^{\mathrm{e}} 6 \mathrm{~W}$ and $5 \mathrm{~W}$ denote the duration from waking to the first e-device use for 6 minutes and 5 minutes, respectively.

${ }^{f} 60 \mathrm{~S}$ and $61 \mathrm{~S}$ denote the duration of e-device use before sleeping for 60 minutes and 61 minutes, respectively.

\section{Interaction Effect Between Demographics and E-Device Use for Psychological Distress}

Subgroup analyses showed that the associations of e-device use before and after sleep with psychological distress differed according to the participants' demographics. Participants who were female, were aged 18 to 44 years, received secondary education or below, or had household income of HK \$39,999 or less showed stronger associations in all but two outcomes; participants who received tertiary education and used e-devices starting $\leq 5$ minutes after waking showed stronger associations with anxiety symptoms, whereas the association between female participants who used e-devices for $\geq 61$ minutes before sleeping and depressive symptoms was not relevant (Tables 6 and 7). 
Table 6. Interaction effect between Hong Kong adults' demographics and e-device use for anxiety symptoms.

\begin{tabular}{|c|c|c|c|c|c|c|}
\hline \multirow[t]{2}{*}{ Characteristic $^{\mathrm{a}}$} & \multicolumn{3}{|c|}{$\begin{array}{l}\text { Duration from waking to the first e-device use ( } \geq 6 \\
\text { min vs } \leq 5 \mathrm{~min} \text { ) }\end{array}$} & \multicolumn{3}{|c|}{$\begin{array}{l}\text { Duration of e-device use before sleeping ( } \leq 60 \mathrm{~min} \\
\text { vs } \geq 61 \mathrm{~min} \text { ) }\end{array}$} \\
\hline & $\mathrm{n}$ & Coefficient $^{\mathrm{b}}$ & $P^{\mathrm{c}}$ & $\mathrm{n}$ & Coefficient $^{\mathrm{b}}$ & $P^{\mathrm{c}}$ \\
\hline Sex & & & $<.001$ & & & .002 \\
\hline Men & 1370 & $0.18(0.02$ to 0.34$)$ & & 1365 & $0.10(-0.07$ to 0.28$)$ & \\
\hline Women & 1629 & 0.47 (0.31 to 0.62$)$ & & 1628 & $0.23(0.03$ to 0.44$)$ & \\
\hline Age (years) $)^{\text {d,e }}$ & & & $<.001$ & & & $<.001$ \\
\hline $18-44$ & 1574 & $0.47(0.32$ to 0.62$)$ & & 1572 & $0.26(0.09$ to 0.44$)$ & \\
\hline$\geq 45$ & 1425 & 0.23 (0.06 to 0.39$)$ & & 1422 & $0.07(-0.14$ to 0.28$)$ & \\
\hline Education $^{d, f}$ & & & $<.001$ & & & $<.001$ \\
\hline Secondary or less & 1984 & $0.28(0.14$ to 0.43$)$ & & 1983 & 0.25 (0.07 to 0.42$)$ & \\
\hline Tertiary or more & 1015 & $0.45(0.27$ to 0.62$)$ & & 1011 & $0.08(-0.12$ to 0.29$)$ & \\
\hline Income $(\mathbf{H K \$})^{\mathbf{d}, \mathrm{g}, \mathrm{h}}$ & & & $<.001$ & & & $<.001$ \\
\hline$\leq 39,999$ & 2006 & 0.45 (0.30 to 0.59$)$ & & 2009 & 0.24 (0.07 to 0.42$)$ & \\
\hline$\geq 40,000$ & 993 & $0.21(0.04$ to 0.38$)$ & & 985 & $0.06(-0.14$ to 0.27$)$ & \\
\hline
\end{tabular}

${ }^{a}$ All data were weighted by sex, age, and education level distribution of the Hong Kong general population.

${ }^{\mathrm{b}}$ Regression coefficient (95\% CI) adjusted for age, sex, highest education level, and monthly household income.

${ }^{\mathrm{c}} P$ value for interaction.

${ }^{\mathrm{d}}$ Demographic variables were summarized into binary groups.

${ }^{\mathrm{e}}$ The median age of the participants was 47 years.

${ }^{\mathrm{f}} 66.9 \%$ and $33.1 \%$ of the Hong Kong population attained secondary education or below and tertiary education, respectively, in 2018.

${ }^{\mathrm{g}}$ The median monthly household income of economically active households in Hong Kong was around HK \$36,000 in 2019.

${ }^{\mathrm{h}}$ Monthly household income (US \$1=HK \$7.8). 
Table 7. Interaction effect between Hong Kong adults' demographics and e-device use for depressive symptoms.

\begin{tabular}{|c|c|c|c|c|c|c|}
\hline \multirow[t]{2}{*}{ Characteristic $^{\mathrm{a}}$} & \multicolumn{3}{|c|}{$\begin{array}{l}\text { Duration from waking to the first e-device use ( } \geq 6 \\
\text { min vs } \leq 5 \mathrm{~min} \text { ) }\end{array}$} & \multicolumn{3}{|c|}{$\begin{array}{l}\text { Duration of e-device use before sleeping ( } \leq 60 \mathrm{~min} \\
\text { vs } \geq 61 \mathrm{~min} \text { ) }\end{array}$} \\
\hline & $\mathrm{n}$ & Coefficient $^{\mathrm{b}}$ & $P^{\mathrm{c}}$ & $\mathrm{n}$ & Coefficient $^{\mathrm{b}}$ & $P^{\mathrm{c}}$ \\
\hline Sex & & & .004 & & & .07 \\
\hline Men & 1371 & $0.21(0.07$ to 0.36$)$ & & 1366 & $0.06(-0.01$ to 0.22$)$ & \\
\hline Women & 1629 & $0.31(0.17$ to 0.44$)$ & & 1629 & $0.04(-0.00$ to 0.07$)$ & \\
\hline Age (years) ${ }^{\text {d,e }}$ & & & $<.001$ & & & $<.001$ \\
\hline $18-44$ & 1574 & $0.36(0.22$ to 0.51$)$ & & 1572 & $0.27(0.11$ to 0.44$)$ & \\
\hline$\geq 45$ & 1426 & 0.19 (0.06 to 0.32$)$ & & 1423 & $0.03(-0.14$ to 0.20$)$ & \\
\hline Education $^{\mathrm{d}, \mathrm{f}}$ & & & $<.001$ & & & .03 \\
\hline Secondary or less & 1984 & $0.28(0.15$ to 0.41$)$ & & 1984 & $0.20(0.05$ to 0.36$)$ & \\
\hline Tertiary or more & 1015 & $0.27(0.12$ to 0.43$)$ & & 1011 & $0.11(-0.07$ to 0.29$)$ & \\
\hline Income $(\text { HK \$) })^{\text {d,g,h }}$ & & & $<.001$ & & & $<.001$ \\
\hline$\leq 39,999$ & 2007 & $0.42(0.29$ to 0.55$)$ & & 2010 & $0.26(0.11$ to 0.42$)$ & \\
\hline$\geq 40,000$ & 993 & $0.03(-0.12$ to 0.17$)$ & & 985 & $0.00(-0.18$ to 0.18$)$ & \\
\hline
\end{tabular}

${ }^{\mathrm{a}}$ All data were weighted by sex, age, and education level distribution of the Hong Kong general population.

${ }^{\mathrm{b}}$ Regression coefficient (95\% CI) adjusted for age, sex, highest education level, and monthly household income.

${ }^{\mathrm{c}} P$ value for interaction.

${ }^{\mathrm{d}}$ Demographic variables were summarized into binary groups.

e The median age of the participants was 47 years.

${ }^{\mathrm{f}} 66.9 \%$ and $33.1 \%$ of the Hong Kong population attained secondary education or below and tertiary education, respectively, in 2018 .

${ }^{\mathrm{g}}$ The median monthly household income of economically active households in Hong Kong was around HK \$36,000 in 2019.

${ }^{\mathrm{h}}$ Monthly household income (US \$1=HK \$7.8).

\section{Discussion}

\section{Principal Findings}

With a large population-representative sample of adult e-device users in Hong Kong, we found that both shorter time to the first e-device use and longer duration of e-device use before sleeping were associated with anxiety and depressive symptoms. The associations tended to be stronger in females, those aged 18 to 44 years, those who received secondary education or below, and those who had household income of HK $\$ 39,999$ or less. To our knowledge, no study has yet presented the associations reported herein. Additionally, this research provides findings of Chinese adults' e-device use in response to the dearth of e-device research in adult populations, particularly those of Chinese ethnicity.

\section{Comparison With Prior Work}

While many studies [8,33-37] have consistently reported that e-device addiction or excessive e-device use is associated with anxiety and depressive symptoms, our study demonstrated that the use of an e-device for more than 60 minutes before sleeping increased the risk of depression and anxiety. Studies have established that excessive e-device use before sleeping (ie, $\geq 61$ $\mathrm{min}$ ) can affect sleep quality. It has been found that the emission of electromagnetic radiation from e-devices impairs the circadian rhythm, and the blue light emitted by e-devices affects melatonin secretion [38-40]. Particularly, one study found that the use of e-devices for over 60 minutes in the evening greatly hindered melatonin secretion at night (mean 48\%, SD 4\%) [40], resulting in poor sleep quality and quantity. Similarly, Hysing et al [22] asserted that using e-devices in the last hour (ie, 60 minutes) before sleeping prolonged sleep onset latency and increased sleep deficiency. Sleep quality [41-43] and melatonin secretion [44-46] are both negatively associated with anxiety and depressive symptoms. Therefore, it can be deduced that poor sleep quantity and quality owing to reduced melatonin secretion from over 60 minutes of e-device use before sleeping, in addition to prolonged exposure to its electromagnetic radiation, can potentially lead to psychological distress. The overall evidence so far suggests that e-devices should not be used for more than 60 minutes before bedtime, and whether such a practice can enhance sleep quality should be investigated.

A high number of public surveys [19,47-49] reported on the pattern of the first e-device use soon after waking as a symptom of the excessive use of e-devices, using descriptive data for the duration. For example, a global survey reported that $33 \%$ of people in developed countries, ranging from $20 \%$ in France to $64 \%$ in South Korea, used smartphones within 5 minutes of waking [47]. In this study, $22.7 \%$ (715/3162) of participants used an e-device within 5 minutes of waking, which is similar to the rate reported in France. Haug et al [13] identified that the duration from waking to the first e-device use was a strong indicator of e-device addiction. In addition to the association between e-device use in the morning and e-device addiction, 
our study showed that the duration from waking to the first e-device use was inversely associated with psychological symptoms.

We identified that there was a strong correlation between the duration from waking to the first e-device use and the duration of e-device use before sleeping. We also identified that the combination of e-device use $\leq 5$ minutes after waking and $\geq 61$ minutes before sleeping showed the highest risk and very high risk for anxiety and depressive symptoms, respectively, as compared with other combinations of e-device use duration. E-device use (particularly with the internet) at bedtime could affect e-device use in the morning. The behavior to immediately use e-devices upon waking is seen as a withdrawal symptom caused by excessive e-device use at bedtime [37,50,51]. In other words, late e-device use at bedtime would cause the first thought on one's mind to use the device again upon waking up as a withdrawal symptom. Lin et al [50] also stressed that a prominent withdrawal behavior of e-device addiction is the pattern of e-device use upon waking (ie, an "eye opener"). The pattern would be a release of the craving to be continuously stimulated by real-time interactions via the e-device (or the internet) immediately upon opening one's eyes in the morning. The "eye opener" concept has also been used to describe withdrawal symptoms of substance use (eg, alcohol and tobacco) in the literature [20,52].

We found that the association between the duration of e-device use and psychological distress differed according to participants' demographics. Although it would be difficult to directly compare our study with existing studies as our findings are novel, some studies have reported that problematic e-device use has been more commonly found among female individuals [13,53-55], younger individuals $[13,56,57]$, those with low education levels [56,57], and those with low household income [56,58,59], which is consistent with our findings. However, the associations were inconsistent in some other studies. For example, de-Sola et al [57] reported that being male had a higher correlation with problematic e-device use than being female, whereas Kim et al [60] found no sex and household income differences. Long et al [12] found that household income was positively associated with problematic e-device use. Hence, a meta-analysis will be useful to affirm the associations of the duration of e-device use and psychological distress with different demographic groups in populations. A qualitative study will also be required to obtain an in-depth understanding of these associations within the Hong Kong context.

Although excessive e-device use is associated with negative health effects, including psychological symptoms, avoiding the use of e-devices cannot be recommended as they are integrated into the daily life of humans in this era owing to their benefits (eg, enhanced communication [61]). Nurturing healthy patterns of device use should be advised. Given that a large number of respondents used e-devices upon waking and before sleeping, public education should be provided for the association between excessive "bedside" e-device use and negative psychological symptoms. Seo et al [18] also identified that a psychosocial intervention could rectify the chemical imbalances in the brain and reduce the negative psychological distress caused by the excessive use of e-devices. Health care professionals can also consider using brief duration indicators to screen for psychological distress among individuals in clinical and community settings.

\section{Limitations}

Our study had several limitations. First, this study only included the e-devices of computers, smartphones, and tablets, and thus, it omitted the use of other e-devices, such as televisions and video game consoles, although most of the content would have involved computers or smartphones. Second, we conducted a probability-based telephone survey. The lack of mobile phone survey data may cause sampling bias. Third, the type of e-device used and the type of online activities conducted on e-devices may affect the durations of e-device use before and after sleep and associated psychological distress. Additional studies would be useful to assess these associations. Fourth, the causal relationships between respondents' use of e-devices and psychological symptoms (eg, psychological distress induces excessive use and vice versa [15]) were uncertain owing to the cross-sectional study design [62]. Fifth, the respondents only included adults; no young people under 18 years old were included. Given that exposure to e-devices begins early in life and that young people rapidly adopt e-devices, the inclusion of young people in future studies would provide a better understanding of the associations between the pattern of e-device use and acute and chronic mental health problems. Finally, all data were self-reported, which might be subject to recall bias and social desirability bias. Future studies should consider including objective data on e-device use and adverse health effects.

\section{Conclusions}

We provided the first findings of the associations of a shorter duration to the first e-device use after waking and a longer duration of e-device use before sleeping with high risks of anxiety and depressive symptoms in adults. Although further studies are required to examine causal relations, these two simple measures could help identify and manage e-device users with high risks for anxiety and depression.

\section{Acknowledgments}

This study was funded by the Hong Kong Jockey Club Charities Trust.

\section{Conflicts of Interest}

None declared.

\section{References}


1. World Health Organization. Public health implications of excessive use of the internet, computers, smartphones and similar electronic devices: meeting report. Geneva: World Health Organization; 2015 Presented at: World Health Organization Meeting; August 27-29, 2014; Main Meeting Hall, Foundation for Promotion of Cancer Research, National Cancer Research Centre, Tokyo, Japan URL: http://apps.who.int/iris/handle/10665/184264

2. The World Bank. Washington, DC: The World Bank; 2016. World Development Report 2016: Digital Dividends URL: http://www.worldbank.org/en/publication/wdr2016 [accessed 2018-07-02]

3. Census and Statistics Department. 2017. Thematic Household Survey Report No. 62: Information technology usage and penetration URL: https://www.statistics.gov.hk/pub/B11302622017XXXXB0100.pdf [accessed 2018-12-23]

4. Pew Research Center. 2016. Smartphone ownership and Internet usage continues to climb in emerging economies URL: http://www.pewglobal.org/2016/02/22/smartphone-ownership-and-internet-usage-continues-to-climb-in-emerging-economies/ [accessed 2018-02-23]

5. Kwon M, Kim D, Cho H, Yang S. The smartphone addiction scale: development and validation of a short version for adolescents. PLoS One 2013;8(12):e83558 [FREE Full text] [doi: 10.1371/journal.pone.0083558] [Medline: 24391787]

6. Mok JY, Choi SW, Kim D, Choi J, Lee J, Ahn H, et al. Latent class analysis on internet and smartphone addiction in college students. Neuropsychiatr Dis Treat 2014;10:817-828 [FREE Full text] [doi: 10.2147/NDT.S59293] [Medline: 24899806]

7. Choi S, Kim D, Choi J, Ahn H, Choi E, Song W, et al. Comparison of risk and protective factors associated with smartphone addiction and Internet addiction. J Behav Addict 2015 Dec;4(4):308-314 [FREE Full text] [doi: 10.1556/2006.4.2015.043] [Medline: 26690626]

8. Demirci K, Akgönül M, Akpinar A. Relationship of smartphone use severity with sleep quality, depression, and anxiety in university students. J Behav Addict 2015 Jun;4(2):85-92 [FREE Full text] [doi: 10.1556/2006.4.2015.010] [Medline: 26132913]

9. World Health Organization. 2019. Gaming disorder URL: https://www.who.int/features/qa/gaming-disorder/en/ [accessed 2019-07-10]

10. Cho H, Kim DJ, Park JW. Stress and adult smartphone addiction: Mediation by self-control, neuroticism, and extraversion. Stress Health 2017 Dec;33(5):624-630. [doi: 10.1002/smi.2749] [Medline: 28332778]

11. Dalbudak E, Evren C, Aldemir S, Coskun KS, Ugurlu H, Yildirim FG. Relationship of internet addiction severity with depression, anxiety, and alexithymia, temperament and character in university students. Cyberpsychol Behav Soc Netw 2013 Apr;16(4):272-278. [doi: 10.1089/cyber.2012.0390] [Medline: 23363230]

12. Long J, Liu T, Liao Y, Qi C, He H, Chen S, et al. Prevalence and correlates of problematic smartphone use in a large random sample of Chinese undergraduates. BMC Psychiatry 2016 Nov 17;16(1):408 [FREE Full text] [doi: 10.1186/s12888-016-1083-3] [Medline: 27855666]

13. Haug S, Castro RP, Kwon M, Filler A, Kowatsch T, Schaub MP. Smartphone use and smartphone addiction among young people in Switzerland. J Behav Addict 2015 Dec;4(4):299-307 [FREE Full text] [doi: 10.1556/2006.4.2015.037] [Medline: 26690625]

14. Lemola S, Perkinson-Gloor N, Brand S, Dewald-Kaufmann JF, Grob A. Adolescents' electronic media use at night, sleep disturbance, and depressive symptoms in the smartphone age. J Youth Adolesc 2015 Mar;44(2):405-418. [doi: 10.1007/s10964-014-0176-x] [Medline: 25204836]

15. Elhai JD, Dvorak RD, Levine JC, Hall BJ. Problematic smartphone use: A conceptual overview and systematic review of relations with anxiety and depression psychopathology. J Affect Disord 2017 Jan 01;207:251-259. [doi: 10.1016/j.jad.2016.08.030] [Medline: 27736736]

16. Enez Darcin A, Noyan C, Nurmedov S, Yilmaz O, Dilbaz N. Smartphone Addiction in Relation with Social Anxiety and Loneliness Among University Students in Turkey. European Psychiatry 2015 Mar;30(1):505. [doi: 10.1016/s0924-9338(15)30398-9]

17. Kim J, Seo M, David P. Alleviating depression only to become problematic mobile phone users: Can face-to-face communication be the antidote? Computers in Human Behavior 2015 Oct;51:440-447. [doi: 10.1016/j.chb.2015.05.030]

18. Seo H, Jeong E, Choi S, Kwon Y, Park H. Neurotransmitters in young people with Internet and smartphone addiction: A comparision with normal controls and changes after cognitive behavioral therapy. : Radiological Society of North America; 2017 Presented at: The Radiological Society of North America's 103rd Scientific Assembly and Annual Meeting (RSNA 2017); November 26-December 1, 2017; Chicago, USA URL: https://press.rsna.org/timssnet/media/pressreleases/14_pr_target. cfm?ID $=1997$

19. IDC. 2013. Always connected: How smartphonessocial keep us engaged URL: https://www.nu.nl/files/ IDC-Facebook\%20Always\%20Connected\%20\%281\%29.pdf [accessed 2018-09-27]

20. Transdisciplinary Tobacco Use Research Center (TTURC) Tobacco Dependence, Baker TB, Piper ME, McCarthy DE, Bolt DM, Smith SS, et al. Time to first cigarette in the morning as an index of ability to quit smoking: implications for nicotine dependence. Nicotine Tob Res 2007 Nov;9 Suppl 4:S555-S570 [FREE Full text] [doi: 10.1080/14622200701673480] [Medline: 18067032]

21. Hale L, Guan S. Screen time and sleep among school-aged children and adolescents: a systematic literature review. Sleep Med Rev 2015 Jun;21:50-58 [FREE Full text] [doi: 10.1016/j.smrv.2014.07.007] [Medline: 25193149] 
22. Hysing M, Pallesen S, Stormark KM, Jakobsen R, Lundervold AJ, Sivertsen B. Sleep and use of electronic devices in adolescence: results from a large population-based study. BMJ Open 2015 Mar 02;5(1):e006748 [FREE Full text] [doi: 10.1136/bmjopen-2014-006748] [Medline: 25643702]

23. Carter B, Rees P, Hale L, Bhattacharjee D, Paradkar MS. Association Between Portable Screen-Based Media Device Access or Use and Sleep Outcomes: A Systematic Review and Meta-analysis. JAMA Pediatr 2016 Dec 01;170(12):1202-1208 [FREE Full text] [doi: 10.1001/jamapediatrics.2016.2341] [Medline: 27802500]

24. Census and Statistics Department. 2018. Thematic Household Survey Report No. 64: Pattern of smoking \& Personal computer and Internet penetration URL: http://www.statistics.gov.hk/pub/B11302642018XXXXB0100.pdf [accessed 2019-07-01]

25. Shen C, Wang MP, Chu JT, Wan A, Viswanath K, Chan SS, et al. Health App Possession Among Smartphone or Tablet Owners in Hong Kong: Population-Based Survey. JMIR Mhealth Uhealth 2017 Jun 05;5(6):e77 [FREE Full text] [doi: 10.2196/mhealth.7628] [Medline: 28583905]

26. Ziersch AM, Baum FE. Involvement in civil society groups: Is it good for your health? J Epidemiol Community Health 2004 Jun;58(6):493-500 [FREE Full text] [doi: 10.1136/jech.2003.009084] [Medline: 15143118]

27. Löwe B, Wahl I, Rose M, Spitzer C, Glaesmer H, Wingenfeld K, et al. A 4-item measure of depression and anxiety: validation and standardization of the Patient Health Questionnaire-4 (PHQ-4) in the general population. J Affect Disord 2010 Apr;122(1-2):86-95. [doi: 10.1016/j.jad.2009.06.019] [Medline: 19616305]

28. Kroenke K, Spitzer RL, Williams JB, Monahan PO, Löwe B. Anxiety disorders in primary care: prevalence, impairment, comorbidity, and detection. Ann Intern Med 2007 Mar 06;146(5):317-325. [doi: 10.7326/0003-4819-146-5-200703060-00004] [Medline: 17339617$]$

29. Löwe B, Kroenke K, Gräfe K. Detecting and monitoring depression with a two-item questionnaire (PHQ-2). J Psychosom Res 2005 Mar;58(2):163-171. [doi: 10.1016/j.jpsychores.2004.09.006] [Medline: 15820844]

30. Leung DY, Lam T, Chan SS. Three versions of Perceived Stress Scale: validation in a sample of Chinese cardiac patients who smoke. BMC Public Health 2010 Aug 25;10:513 [FREE Full text] [doi: 10.1186/1471-2458-10-513] [Medline: 20735860]

31. Census and Statistics Department. 2015. Hong Kong Population Projections 2015-2064 URL: https://www.statistics.gov.hk/ pub/B1120015062015XXXXB0100.pdf [accessed 2019-07-11]

32. Barros AJ, Hirakata VN. Alternatives for logistic regression in cross-sectional studies: an empirical comparison of models that directly estimate the prevalence ratio. BMC Med Res Methodol 2003 Oct 20;3:21 [FREE Full text] [doi: 10.1186/1471-2288-3-21] [Medline: 14567763]

33. Harwood J, Dooley JJ, Scott AJ, Joiner R. Constantly connected - The effects of smart-devices on mental health. Computers in Human Behavior 2014 May;34:267-272. [doi: 10.1016/j.chb.2014.02.006]

34. Hong F, Chiu S, Huang D. A model of the relationship between psychological characteristics, mobile phone addiction and use of mobile phones by Taiwanese university female students. Computers in Human Behavior 2012 Nov;28(6):2152-2159. [doi: 10.1016/j.chb.2012.06.020]

35. Elhai JD, Tiamiyu M, Weeks J. Depression and social anxiety in relation to problematic smartphone use. Internet Research 2018 Apr 04;28(2):315-332. [doi: 10.1108/intr-01-2017-0019]

36. Hwang K, Yoo Y, Cho O. Smartphone Overuse and Upper Extremity Pain, Anxiety, Depression, and Interpersonal Relationships among College Students. The Journal of the Korea Contents Association 2012 Oct 28;12(10):365-375. [doi: 10.5392/jkca.2012.12.10.365]

37. Matar Boumosleh J, Jaalouk D. Depression, anxiety, and smartphone addiction in university students- A cross sectional study. PLoS One 2017;12(8):e0182239 [FREE Full text] [doi: 10.1371/journal.pone.0182239] [Medline: 28777828]

38. Lee Y, Low B. Sleep pattern among electronic device users and its relationship with users' practice in Malaysia university community. Sleep Biol. Rhythms 2016 Feb 8;14(3):271-277. [doi: 10.1007/s41105-016-0052-z]

39. Cain N, Gradisar M. Electronic media use and sleep in school-aged children and adolescents: A review. Sleep Med 2010 Sep;11(8):735-742. [doi: 10.1016/j.sleep.2010.02.006] [Medline: 20673649]

40. Wood B, Rea MS, Plitnick B, Figueiro MG. Light level and duration of exposure determine the impact of self-luminous tablets on melatonin suppression. Appl Ergon 2013 Mar;44(2):237-240. [doi: 10.1016/j.apergo.2012.07.008] [Medline: 22850476]

41. Alvaro P, Roberts R, Harris JK. A Systematic Review Assessing Bidirectionality between Sleep Disturbances, Anxiety, and Depression. Sleep 2013 Jul 01;36(7):1059-1068 [FREE Full text] [doi: 10.5665/sleep.2810] [Medline: 23814343]

42. Augner C. Associations of Subjective Sleep Quality with Depression Score, Anxiety, Physical Symptoms and Sleep Onset Latency in Young Students. Cent Eur J Public Health 2011 Jun 1;19(2):115-117. [doi: 10.21101/cejph.a3647]

43. De-Sola Gutiérrez J, Rodríguez de Fonseca F, Rubio G. Cell-Phone Addiction: A Review. Front Psychiatry 2016;7:175 [FREE Full text] [doi: 10.3389/fpsyt.2016.00175] [Medline: 27822187]

44. Sundberg I, Ramklint M, Stridsberg M, Papadopoulos FC, Ekselius L, Cunningham JL. Salivary Melatonin in Relation to Depressive Symptom Severity in Young Adults. PLoS One 2016 Apr 4;11(4):e0152814 [FREE Full text] [doi:

10.1371/journal.pone.0152814] [Medline: 27042858] 
45. Hansen MV, Andersen LT, Madsen MT, Hageman I, Rasmussen LS, Bokmand S, et al. Effect of melatonin on depressive symptoms and anxiety in patients undergoing breast cancer surgery: a randomized, double-blind, placebo-controlled trial. Breast Cancer Res Treat 2014 Jun;145(3):683-695. [doi: 10.1007/s10549-014-2962-2] [Medline: 24756186]

46. Hansen M, Halladin N, Rosenberg J, Gögenur I, Møller AM. Melatonin for pre- and postoperative anxiety in adults. Cochrane Database Syst Rev 2015 Apr 09(4):CD009861 [FREE Full text] [doi: 10.1002/14651858.CD009861.pub2] [Medline: 25856551]

47. Deloitte. 2017. Global mobile consumer trends, 2nd edition: Mobile continues its global reach into all aspects of consumers' lives URL: https://www2.deloitte.com/content/dam/Deloitte/global/Documents/Technology-Media-Telecommunications/ gx-global-mobile-consumer-survey-2nd-edition.pdf [accessed 2018-05-16]

48. Lookout. 2012. Mobile mindset study URL: https://www.tecnostress.it/wp-content/uploads/2012/12/ lookout-mobile-mindset-2012.pdf [accessed 2017-05-05]

49. Montag C, Kannen C, Lachmann B, Sariyska R, Duke É, Reuter M, et al. The importance of analogue zeitgebers to reduce digital addictive tendencies in the 21st century. Addict Behav Rep 2015 Dec;2:23-27 [FREE Full text] [doi: 10.1016/j.abrep.2015.04.002] [Medline: 29531991]

50. Lin Y, Chang L, Lee Y, Tseng H, Kuo TB, Chen S. Development and validation of the Smartphone Addiction Inventory (SPAI). PLoS One 2014;9(6):e98312 [FREE Full text] [doi: 10.1371/journal.pone.0098312] [Medline: 24896252]

51. Lin Y, Lin S, Yang C, Kuo T. Psychopathology of everyday life in the 21st century: smartphone addiction. In: Montag C, Reuter M, editors. Internet addiction: Neuroscientific approaches and therapeutical implications including smartphone addiction. Switzerland: Springer; 2017:339-358.

52. Bush B, Shaw S, Cleary P, Delbanco TL, Aronson MD. Screening for alcohol abuse using the cage questionnaire. The American Journal of Medicine 1987 Feb;82(2):231-235. [doi: 10.1016/0002-9343(87)90061-1]

53. Billieux J, Van der Linden M, Rochat L. The role of impulsivity in actual and problematic use of the mobile phone. Appl. Cognit. Psychol 2008 Dec;22(9):1195-1210. [doi: 10.1002/acp.1429]

54. Yang S, Lin C, Huang Y, Chang J. Gender differences in the association of smartphone use with the vitality and mental health of adolescent students. J Am Coll Health 2018 Oct;66(7):693-701. [doi: 10.1080/07448481.2018.1454930] [Medline: 29565784]

55. Chen B, Liu F, Ding S, Ying X, Wang L, Wen Y. Gender differences in factors associated with smartphone addiction: a cross-sectional study among medical college students. BMC Psychiatry 2017 Oct 10;17(1):341 [FREE Full text] [doi: 10.1186/s12888-017-1503-z] [Medline: 29017482]

56. Alhassan AA, Alqadhib EM, Taha NW, Alahmari RA, Salam M, Almutairi AF. The relationship between addiction to smartphone usage and depression among adults: a cross sectional study. BMC Psychiatry 2018 May 25;18(1):148 [FREE Full text] [doi: 10.1186/s12888-018-1745-4] [Medline: 29801442]

57. de-Sola J, Talledo H, Rodríguez de Fonseca F, Rubio G. Prevalence of problematic cell phone use in an adult population in Spain as assessed by the Mobile Phone Problem Use Scale (MPPUS). PLoS One 2017;12(8):e0181184 [FREE Full text] [doi: 10.1371/journal.pone.0181184] [Medline: 28771626]

58. Sahin S, Ozdemir K, Unsal A, Temiz N. Evaluation of mobile phone addiction level and sleep quality in university students. Pak J Med Sci 2013 Jul;29(4):913-918 [FREE Full text] [doi: 10.12669/pjms.294.3686] [Medline: 24353658]

59. Aljomaa SS, Al.Qudah MF, Albursan IS, Bakhiet SF, Abduljabbar AS. Smartphone addiction among university students in the light of some variables. Computers in Human Behavior 2016 Aug;61:155-164. [doi: 10.1016/j.chb.2016.03.041]

60. Kim H, Min J, Min K, Lee T, Yoo S. Relationship among family environment, self-control, friendship quality, and adolescents' smartphone addiction in South Korea: Findings from nationwide data. PLoS One 2018;13(2):e0190896 [FREE Full text] [doi: 10.1371/journal.pone.0190896] [Medline: 29401496]

61. Wang MP, Chu JT, Viswanath K, Wan A, Lam TH, Chan SS. Using Information and Communication Technologies for Family Communication and Its Association With Family Well-Being in Hong Kong: FAMILY Project. J Med Internet Res 2015 Aug 24;17(8):e207 [FREE Full text] [doi: 10.2196/jmir.4722] [Medline: 26303434]

62. Carlson MD, Morrison RS. Study design, precision, and validity in observational studies. J Palliat Med 2009 Jan;12(1):77-82 [FREE Full text] [doi: 10.1089/jpm.2008.9690] [Medline: 19284267]

\author{
Abbreviations \\ ANOVA: analysis of variance \\ FHInTS: Family and Health Information Trends Survey \\ GAD-2: Generalized Anxiety Disorder-2 \\ ICT: information and communication technology \\ PHQ-2: Patient Health Questionnaire-2 \\ PHQ-4: Patient Health Questionnaire-4 \\ PR: prevalence ratio \\ WHO: World Health Organization
}


Edited by G Eysenbach; submitted 14.07.19; peer-reviewed by W Fuzhi, YH Lin, L Guan; comments to author 24.12.19; revised version received 07.02.20; accepted 20.04.20; published 11.06.20

Please cite as:

Lee JJ, Wang MP, Luk TT, Guo N, Chan SSC, Lam TH

Associations of Electronic Device Use Before and After Sleep With Psychological Distress Among Chinese Adults in Hong Kong: Cross-Sectional Study

JMIR Ment Health 2020;7(6):e15403

URL: http://mental.jmir.org/2020/6/e15403/

doi: $\underline{10.2196 / 15403}$

PMID: $\underline{32525489}$

(CJung Jae Lee, Man Ping Wang, Tzu Tsun Luk, Ningyuan Guo, Sophia Siu-Chee Chan, Tai Hing Lam. Originally published in JMIR Mental Health (http://mental.jmir.org), 11.06.2020. This is an open-access article distributed under the terms of the Creative Commons Attribution License (https://creativecommons.org/licenses/by/4.0/), which permits unrestricted use, distribution, and reproduction in any medium, provided the original work, first published in JMIR Mental Health, is properly cited. The complete bibliographic information, a link to the original publication on http://mental.jmir.org/, as well as this copyright and license information must be included. 